\title{
To study duration of viral clearance in COVID 19 patients: A Prospective study from Bangalore, India
}

\author{
Swetha Rajoli ${ }^{1}$, Avinash Hanbe Rajanna ${ }^{2}$, Sumesh Yadav ${ }^{3}$ \\ ${ }^{1}$ Assistant Professor, Department of Anesthesia, ESIC Medical College, Rajajinagar, Bangalore, Karnataka, India \\ ${ }^{2}$ Assistant Professor, ${ }^{3}$ Post-Graduate Trainee, Department of Medicine, Bangalore Medical College and Research \\ Institute, KR road, Bangalore, Karnataka, India
}

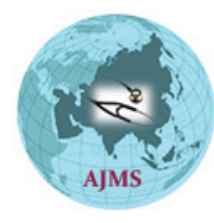

A B S T R A C T

Background: COVID-19 infection, which first reported as a cluster of pneumonia from Wuhan, China, in December 2019, has rapidly emerged as a global pandemic. During the early course of the pandemic. The duration of infectious virus replication is an important factor for clinicians. There is a significant correlation between the duration of SARS-CoV-2 virus clearance and the prognosis of COVID-19. Aims and Objective: To study Duration of viral clearance in COVID 19 patients, admitted in an Indian setting. Materials and Methods: The prospective single-center study considered adults patients of both the gender, diagnosed with COVID-19 infection by RT-PCR technique. Necessary demographic and clinical data were collected and selected subjects were followed-up until discharge or death. Based on the number of days required for viral clearance, the subjects were classified as: group 1: $\leq 14$ days, group 2: 1528 days, and group 3: $>28$ days. Results: The study included 536 patients it was found that mean duration required for viral clearance was around $8.98 \pm 3.54$. Mean ages noted for group 1, 2 and 3 (based on viral clearance) were $37.57 \pm 13.65$ years, $37.12 \pm 13.73$ years and $49.50 \pm 23.56$ years respectively. There was a significant difference between mean age of group 1 and 2, as well as group 1 and 3. Moreover, the distribution of patients across different age group was found to be statistically significant $(P<0.05)$. Significant difference was noted between three groups with respect to the comorbidity status $(P<0.0001)$. The COVID-related symptoms dyspnea and cough were more prominent in group $3(P<0.05)$. TLC which is statistically significant $(p<0.05)$, lower the TLC more the duration of viral clearance and more the duration of hospital stay. Conclusion: The mean days of viral clearance noted in COVID subjects is around $8.98 \pm 3.54$ days. There was a significant difference between mean age of group 1 and 2, as well as group 1 and 3 . However, there is no statistically significant correlation between duration of hospital stay and inflammatory markers except TLC which is statistically significant $(p<0.05)$, lower the TLC more the duration of viral clearance and more the duration of hospital stay.

Keywords: COVID-19; Viral clearance; Inflammatory markers; Total leucocyte count

\section{Access this article online}

\section{Website:}

http://nepjol.info/index.php/AJMS DOI: $10.3126 /$ ajms.v12i8.37799

E-ISSN: 2091-0576

P-ISSN: 2467-9100

Copyright (c) 2021 Asian Journal of Medical Sciences

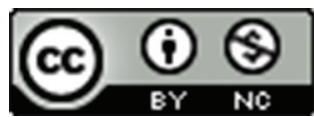

This work is licensed under a Creative Commons Attribution-NonCommercial 4.0 International License.

\section{INTRODUCTION}

COVID-19 infection, which first reported as a cluster of pneumonia from Wuhan, China, in December 2019, has rapidly emerged as a global pandemic. ${ }^{1}$ During the early course of the pandemic, Italy had the highest infection burden and India remained much less affected with corresponding mortality rates of $14.24 \%$ and $3.03 \% .{ }^{2}$ The total cases in India has now crossed 29 million mark and officially confirmed deaths being 382785 , according to the Health Ministry data published on June16, 2021.

The incubation period of SARS-CoV-2 ranges from 1 to 14 days, with a mean of 5 to 6 days. The first studies 
indicated that the viral load persisted up to 8 days after the onset of symptoms in mild cases and peaked in day 11 in more severe cases. ${ }^{3,4}$ The duration of infectious virus replication is an important factor for clinicians. There is a significant correlation between the duration of SARSCoV-2 virus clearance and the prognosis of COVID-19. A longer duration of viral clearance in adult patients with COVID-19 increases the risk of death. ${ }^{5}$ However, upon the resolution of clinical symptoms the clearance of SARS-CoV-2 from respiratory samples remains unclear, making the establishment of patient discharge and the ending isolation criteria difficult COVID-19 patients may be discharged based on clinical resolution of symptoms, and evidence for viral RNA clearance from the upper respiratory tract. Understanding the SARS-CoV-2 viral clearance profile is crucial to establish a retesting plan on discharge and ending isolation of patients. We aimed to evaluate the number of days that a patient needed to achieve undetectable levels of SARS-CoV-2 in upper respiratory tract specimens (nasopharyngeal swab and/or an oropharyngeal swab).

\section{MATERIALS AND METHODS}

The prospective study was carried out between March and May 2020 at a Bengaluru-based hospital setting. Approval and clearance were obtained from the Institutional ethics committee. The study included patients aged $\geq 18$ years of both the gender, diagnosed with COVID-19 infection by RT-PCR technique. The study excluded patients $<18$ years and those not willing to provide signed informed consent prior to the study. Case record form with follow-up chart was used to record the demographic data, and duration and clinical features of the disease.

Case record form with follow-up chart was used to record the demographic data, and duration and clinical features of the disease. Patients' data like clinical symptoms and incidence of co-morbidities like hypertension, diabetes, and metabolic disorders like renal, cardiac and respiratory disorders were collected biochemical reports were collected (CBC, LDH, CRP, Ferritin and D-Dimer). Based on the number of days required for viral clearance, the subjects were classified as: group 1: $\leq 14$ days, group 2: 15-28 days, and group 3:>28 days.

\section{Statistical analysis}

Carried out using software $\mathrm{R}$ version 3.6. Continuous variables were expressed as means, and standard deviation and categorical variables were presented as counts and percentages. Patients were grouped as survival and succumbed to death. Different parameters were compared between the groups using t-test for continues and chi-square test for categorical data. The optimal cut points were estimated for significant continuous variables using receiver operating curve (ROC) analysis. Multiple regression analysis was carried out and odds ratio with confidence interval $(\mathrm{CI})$ were estimated to determine the effect of significant factors on outcome death and survival. For evaluating the mean days of viral clearance, many mild and moderate cases were not considered due to the implementation of the revised third discharge policy. P value $<0.05$ was considered as statistically significant.

\section{RESULTS}

Out of 536 patients who had viral clearance information,449 (83.77\%), 121(22.58\%) and 6(1.12\%) patients were categorized into group 1,2 and 3 respectively. The overall mean viral clearance time for 536 patients was found to be $8.98 \pm 3.54$ days.

Comparison of different variables across the different groups is shown (Table 1). Mean ages noted forgroup1, 2 and 3 were $37.57 \pm 13.65$ years, $37.12 \pm 13.73$ years and $49.50 \pm 23.56$ years respectively. There was a significant difference between mean age of group 1 and 2, as well as group 1 and 3. Moreover, the distribution of patients across different age group was found to be statistically significant $(\mathrm{P}<0.05)$. The maximum number of patients belonged to the age group of 30-39 years and least number of patients in $\geq 70$ years.

Significant difference was noted between three groups with respect to the comorbidity status $(\mathrm{P}<0.0001)$. In the group 3 , around $33 \%$ of the subjects had diabetes as opposed to only around $5 \%$ in group 1 , and $2.50 \%$ of the subjects belonging to the group 3 and other ICU facilities when compared to the other two groups $(\mathrm{P}<0.0016)$ (Table 2$)$.

No Significant difference was noted between three groups with respect to the inflammatory markers Except TLC which is statistically significant $(\mathrm{p}<0.05)$ lower the TLC

\begin{tabular}{|c|c|c|c|c|}
\hline Variable & $\begin{array}{l}\text { Group } 1 \\
(n=449)\end{array}$ & $\begin{array}{l}\text { Group 2 } \\
(n=121)\end{array}$ & $\begin{array}{c}\text { Group } 3 \\
(n=6)\end{array}$ & $P$ value \\
\hline Age (years) & $\begin{array}{l}37.57 \pm \\
13.65^{a}\end{array}$ & $\begin{array}{l}37.12 \pm \\
13.73^{b}\end{array}$ & $\begin{array}{l}49.50 \pm \\
23.56^{b}\end{array}$ & $<0.001$ \\
\hline \multicolumn{5}{|l|}{ Age Group } \\
\hline$<30$ years, $\mathrm{n}(\%)$ & $160(35.63)$ & $42(34.71)$ & $0(0)$ & $<0.00001$ \\
\hline $30-40$ years, $n(\%)$ & $118(26.28)$ & $32(26.45)$ & $3(50.00)$ & \\
\hline $40-50$ years, $n(\%)$ & $78(17.37)$ & $22(18.18)$ & $1(16.67)$ & \\
\hline $50-60$ years, $n(\%)$ & $53(11.80)$ & $14(11.57)$ & $0(0)$ & \\
\hline $60-70$ years, $n(\%)$ & $33(7.35)$ & $10(8.26)$ & $1(16.67)$ & \\
\hline$\geq 70$ years, $\mathrm{n}(\%)$ & $7(1.56)$ & $1(0.83)$ & 1(16.67) & \\
\hline
\end{tabular}




\begin{tabular}{|c|c|c|c|c|}
\hline Variable & $\begin{array}{l}\text { Group } 1 \\
(n=449)\end{array}$ & $\begin{array}{l}\text { Group } 2 \\
(n=121\end{array}$ & $\begin{array}{c}\text { Group } 3 \\
(n=6)\end{array}$ & $P$ value \\
\hline \multicolumn{5}{|l|}{ Comorbidities } \\
\hline None & $310(69.04)$ & $74(61.16)$ & $3(50.00)$ & $<0.00001$ \\
\hline Diabetes only & $25(5.57)$ & $6(4.96)$ & $2(33.33)$ & \\
\hline $\begin{array}{l}\text { Hypertension } \\
\text { only }\end{array}$ & $21(4.68)$ & $4(3.13)$ & $0(0)$ & \\
\hline $\begin{array}{l}\text { Diabetes or } \\
\text { Hypertension } \\
\text { with other } \\
\text { complications }\end{array}$ & $38(8.46)$ & $16(13.22)$ & $0(0)$ & \\
\hline $\begin{array}{l}\text { Chronic Kidney } \\
\text { disease }\end{array}$ & $0(0)$ & $0(0)$ & $0(0$ & \\
\hline Other & $55(12.25)$ & $62(51.20)$ & $1(16.67)$ & \\
\hline ICU requirement & $25(5.57)$ & $17(14.05)$ & $3(50.00)$ & $<0.0000$ \\
\hline $\begin{array}{l}\text { Asymptomatic, } \\
\mathrm{n}(\%)\end{array}$ & $316(70.38)$ & $81(66.94)$ & $3(50.00)$ & 0.4469 \\
\hline
\end{tabular}

more the duration of viral clearance and more the duration of hospital stay (Table 3).

In all the three groups categorized based on viral clearance, more than half of the subjects were asymptomatic $(>50 \%)$. The COVID-related symptoms dyspnea and cough were more prominent in group $3(\mathrm{P}<0.05)$ and the other symptoms like fever, myalgia, sore throat and headache were not significantly differed between the groups $(\mathrm{P}>0.05)$. The corresponding number of subjects who succumbed to death in group 1, 2 and 3 were $42(9.35 \%)$, $0(0 \%)$ and $1(17.63 \%)$ respectively (P 0.0187$)$.

\section{DISCUSSION}

The present study found that viral clearance time for 536 patients was found to be $8.98 \pm 3.54$ day as the mean time for final viral clearance in subjects. Carmo et al., observed the persistence of viral RNA for more than 2 weeks, which may not be linked to disease severity, but with a weaker immune response. ${ }^{6}$ Samrah et al., found median viral shedding duration of 13 days. Patients having symptoms or/and the presence of abnormal radiological findings were associated with delayed viral clearance. Symptomatic COVID-19 patients may still have respiratory viral shedding for up to 20 days after clinical cure. ${ }^{7}$

\section{Age distribution}

Mean ages noted for group 1,2 and 3 were $37.57 \pm 13.65$ years, $37.12 \pm 13.73$ years and $49.50 \pm 23.56$ years respectively. There was a significant difference between mean age of group 1 and 2, as well as group 1 and 3. Moreover, the distribution of patients across different age group was found to be statistically significant $(\mathrm{P}<0.05)$. Hirai et al.,

\begin{tabular}{lcccc}
\multicolumn{5}{l}{ Table 3: Correlation of Inflammatory markers } \\
\hline $\begin{array}{lccc}\text { Laboratory } \\
\text { parameters }\end{array}$ & $\begin{array}{c}\text { Group 1 } \\
(\mathbf{n}=\mathbf{4 4 9 )}\end{array}$ & $\begin{array}{c}\text { Group 2 } \\
(\mathbf{n}=121)\end{array}$ & $\begin{array}{c}\text { Group 3 } \\
(\mathbf{n}=\mathbf{6}\end{array}$ & P value \\
\hline Hemoglobin & $13.26 \pm 2.33$ & $13.17 \pm$ & $13.13 \pm$ & 0.9223 \\
& & 2.15 & 1.15 & \\
Total & $8126 \pm$ & $7516 \pm$ & $5717 \pm$ & 0.0114 \\
Leucocyte & $2740.56^{\mathrm{a}}$ & $2621.08^{\mathrm{b}}$ & $2316.39^{\times}$ & \\
count & & & & \\
Neutrophil & $61.52 \pm$ & $59.85 \pm$ & $58.00 \pm$ & 0.3007 \\
& 11.29 & 12.91 & 7.62 & \\
Lymphocytes & $28.75 \pm$ & $29.37 \pm$ & $30.83 \pm$ & 0.7539 \\
& 10.08 & 10.90 & 6.68 & \\
Neutrophils & $2.64 \pm$ & $2.73 \pm$ & $2.02 \pm$ & 0.6603 \\
lymphocytes & 1.80 & 2.50 & 0.83 & \\
ratio & & & & \\
LDH & $245.80 \pm$ & $243.5 \pm$ & $281.30 \pm$ & 0.6802 \\
& 105.33 & 96.17 & 39.83 & \\
D-dimer & $0.75 \pm$ & $1.65 \pm$ & $0.73 \pm$ & 0.1015 \\
& 0.63 & 8.89 & 0.29 & \\
C-Reactive & $13.28 \pm$ & $16.13 \pm$ & $32.07 \pm$ & 0.3753 \\
Protein & 35.16 & 44.25 & 45.04 & \\
Ferritin & $212.60 \pm$ & $222.35 \pm$ & $312.8 \pm$ & 0.6987 \\
& 301.19 & 316.87 & 206.67 &
\end{tabular}

Group $1=\leq 14$ days, Group $2=14-28$ days and Group $3=>28$ days; statistically significant if $\mathrm{P}<0.05$; different superscript across the row differ significantly $(P<0.05$ for $\mathrm{t}$-test)

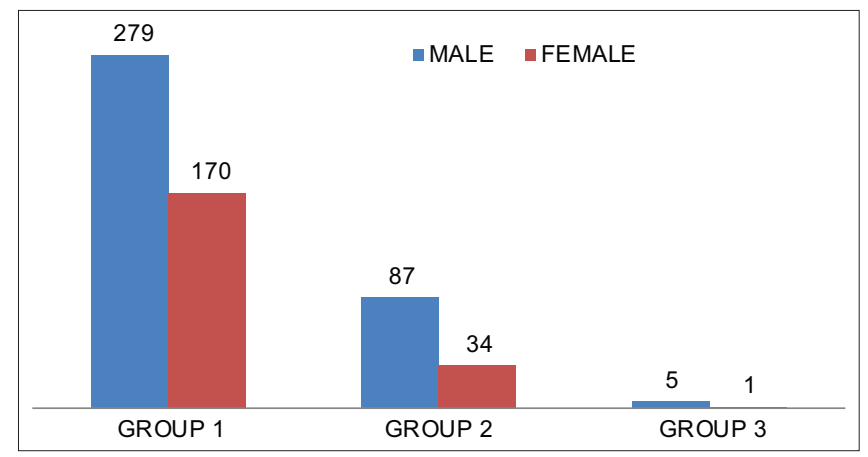

Figure 1: Sex distribution among groups

observed that the younger patients who recovered from COVID-19 took less time to clear SARS-CoV-2 compared to the elderly patients; thus, a classification of the isolation periods based on age could be considered. ${ }^{8}$ Male $62.14 \%$ in Group1, $71.9 \%$ in Group 2, 83.3\% in Group3, Female $37.8 \%$ in Group 1, 28.10\% in Group 2, 16.67\% in Group 3 respectively (Figure 1).

\section{Comorbidities}

Significant difference was noted between three groups with respect to the comorbidity status $(\mathrm{P}<0.0001)$. In the group 3, around $33 \%$ of the subjects had diabetes as opposed to only around $5 \%$ in group 1, and $2.50 \%$ of the subjects belonging to the group 3. Shu et al., reported in their study that delayed admission and underlying comorbidities may effectively predict SARS-CoV-2 RNA clearance. ${ }^{9}$ Abrahim et al., showed in their study that those participants without comorbidities recovered more quickly 
than those with at least one comorbidity. ${ }^{10}$ Trump et al., in their study reported hypertension as one of the factors which causes delay of viral clearance and exacerbates airway hyperinflammation in patients with COVID-19. ${ }^{11}$

\section{Correlation with Inflammatory markers}

In the current study, the total leukocyte count (TLC) was found to be statistically significant with respect to the viral clearance, lower the TLC more the duration of viral clearance and more the duration of hospital stay $(\mathrm{p}<0.05)$, whereas the there was no statistically significant correlation between CRP, D-Dimer, Ferritin levels with viral clearance. In a study conducted by Xue et al., reported those patients with history of hypertension, an elevated IL-6 level, and an elevated percentage of NK cells were predisposed to higher risk with prolonged viral clearance. ${ }^{12}$

\section{CONCLUSION}

The present study has underscored maximum of around $8.98 \pm 3.54$ days as mean days of viral clearance required in most of the COVID positive patients. There was a significant difference between mean age of group 1 and 2 , as well as group 1 and 3 .

There is no statistically significant correlation between duration of hospital stay and inflammatory markers except TLC which is statistically significant $(p<0.05)$, lower the TLC more the duration of viral clearance and more the duration of hospital stay.

Limitations of the study

Single centered study and small sample size.

\section{ACKNOWLEDGEMENT}

The authors take this opportunity to thank BMCRI for their whole hearted support for this study.

\section{REFERENCES}

1. WHO | Pneumonia of unknown cause - China [Internet]. WHO World Health Organization; [cited 2020 Nov 4]. Available from: http://www.who.int/csr/don/05-january-2020-pneumonia-of- unkown-cause-china/en

2. John TJ and Seshadri MS. COVID-19 Mortality Trends and Reporting. Economic and Political Weekly. 2015;55(37):7-8.

3. Huang C, Wang Y, Li X, Ren L, Zhao J, Hu Y, et al. Clinical features of patients infected with 2019 novel coronavirus in Wuhan, China. Lancet (London, England), 395(10223), 497-506. https://doi.org/10.1016/S0140-6736(20)30183-5

4. Gupta N, Agrawal S, Ish P, Mishra S, Gaind R, Usha G, et al. Clinical and epidemiologic profile of the initial COVID-19 patients at a tertiary care centre in India. Monaldi archives for chest disease. 2020; 90(1):

https://doi.org/10.4081/monaldi.2020.1294

5. Chang D, Mo G, Yuan X, Tao Y, Peng X, Wang F-S, et al. Time Kinetics of Viral Clearance and Resolution of Symptoms in Novel Coronavirus Infection. American Journal of Respiratory and Critical Care Medicine. 2020;201(9):1150-1152.

https://doi.org/10.1164/rccm.202003-0524LE

6. Carmo A, Pereira-Vaz J, Mota V, Mendes A, Morais C, Silva AC, et al. Clearance and persistence of SARS-CoV-2 RNA in patients with COVID-19. Journal of Medical Virology. 2020;92(10):2227-2231. https://doi.org/10.1002/jmv.26103

7. Samrah SM, Al-Mistarehi AH, Kewan T, Al-Khatib SM, Ibnian AM, Samrah, RS, et al. Viral Clearance Course of COVID-19 Outbreaks. Journal of multidisciplinary healthcare. 2021;14: 555-565.

https://doi.org/10.2147/JMDH.S302891

8. Hirai $N$, Nishioka $\mathrm{Y}$, Sekine $\mathrm{T}$, Nishihara $\mathrm{Y}$, Okuda $\mathrm{N}$, Nishimura T, et al. Factors associated with viral clearance periods from patients with COVID-19: A retrospective observational cohort study. Journal of infection and chemotherapy: Official journal of the Japan Society of Chemotherapy. 2021;27(6): 864-868. https://doi.org/10.1016/j.jiac.2021.02.015

9. Shu HM, He S, Sun Y, Lin CQ, Lu YF, Liu J, et al. Factors Influencing Viral Clearance in Mild COVID-19 and Clinical Characteristics of Asymptomatic Patients. BioMed research international. 2021; 5909612. https://doi.org/10.1155/2021/5909612

10. Abrahim SA, Tessema M, Defar A, Hussen A, Ejeta $E$, Demoz G, et al. Time to recovery and its predictors among adults hospitalized with COVID-19: A prospective cohort study in Ethiopia. PloS ONE. 2020; 15(12): e0244269. https://doi.org/10.1371/journal.pone.0244269

11. Trump S, Lukassen S, Anker MS, Chua RL, Liebig J, Thürmann, et al. Hypertension delays viral clearance and exacerbates airway hyperinflammation in patients with COVID-19. Nature Biotechnology. 2020; 39(6):705-716. https://doi.org/10.1038/s41587-020-00796-1

12. Xue J, Zheng J, Shang X, Qin E, Zhao P, He Y, et al. Risk factors for prolonged viral clearance in adult patients with COVID-19 in Beijing, China: A prospective observational study. International immunopharmacology. 2020;89(Pt A): 107031

https://doi.org/10.1016/j.intimp.2020.107031

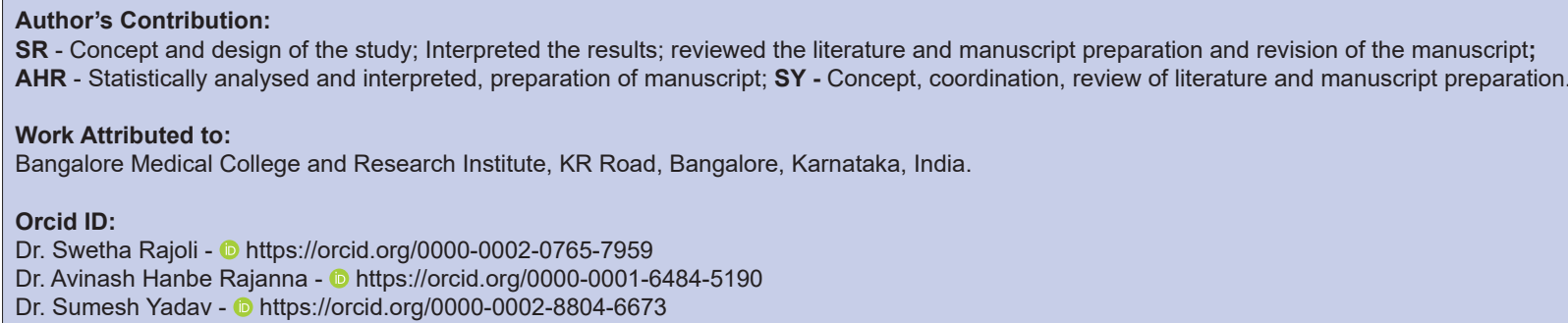

